\title{
CONVERGENCE OF THE MAIN SUSTAINABLE CONSUMPTION AND PRODUCTION INDICATORS IN NEW EU MEMBER STATES 2000-2010
}

\author{
INGA UŽDANAVIČIŪTĖ ${ }^{1}$, RENATA DAGILIŪTĖ $^{2}$ \\ Vytautas Magnus University (Lithuania)
}

\begin{abstract}
Convergence is one the main targets of enlarged EU. According to the analysis of the main sustainable consumption and production indicators, except domestic material consumption, convergence has been taking place in new EU member states over the period of economic growth in 2000-2007. However, as indicated by the results due to the global economic crisis in 2009 differences between the countries have increased: the convergence rate - the coefficient of variation - increased. In overall terms, countries in CEE have improved in most cases and converged to the average of the group. However, in terms of sustainable development, convergence not always indicates positive changes. New EU member states while striving to reach higher economic level should maintain lower levels of consumption, waste generation and pollution. Much more attention to energy and resource efficiency and decoupling of economic growth and resource consumption is to be paid.

KEYWORDS: Central and Eastern Europe, sustainable consumption and production, sustainable region's development, convergence.
\end{abstract}

JEL CODE: Q560, R110, O570, Q010

\section{Introduction}

A significant dependence on the natural resources and high levels of consumption in developed countries together with growing consumption levels in developing countries raises a serious threat to global sustainable development processes. Thus, implementation of sustainable development principles is very important on both production and consumption side.

The European Union is one of the most prosperous economies in the world, but the differences between the parties are striking, and between regions are dramatic. Regional inequalities are mainly due to the large income disparities between EU regions (Šidlauskienè, 2000). Hence, EU priority is economic, environmental and social convergence between the member states. In accordance with the $158^{\text {th }}$ article of Treaty of European Union (2006) reduction of the disparities in the level of development of the various regions should be achieved (Armstrong, Taylor, 2004). And more and more countries are interested in EU cohesion policy model for sustainable development and new opportunities (Kasinskaite, 2005).

Inga Uždanavičiūtè - M. Sc. Vytautas Magnus University, Department of Environmental Sciences, PhD student. Scientific interests: sustainable development, environmental health

E-mail: i.uzdanaviciute@gmf.vdu.lt

Tel.: +370 37327904 .

2 Renata Dagiliūte - Dr. Vytautas Magnus University, Natural Sciences Faculty, Environmental Studies Department, lecturer.

Scientific interests: sustainable development, sustainable consumption and production

E-mail: r.dagiliute@gmf.vdu.lt

Tel.: +370 37327904 . 
New EU member's economies generally are growing faster than the EU15, hence they are catching-up and some similar development level should be achieved. Despite that, inequality persists and convergence between countries is slow. In addition, usually only convergence of economic aspects is analysed. Therefore, the main aim of this study is to assess convergence of the main sustainable consumption and production indicators in new Central and Eastern European EU Members States (since 2004) over 2000-2010.

The object of the study is convergence of sustainable consumption and production indicators over 20002010 year period in new EU Member States. Eight countries in Central and Eastern Europe: Czech Republic, Estonia, Latvia, Lithuania, Hungary, Poland, Slovenia and Slovakia, which became members of the European Union on the $1^{\text {st }}$ of May in 2004, are chosen for the analysis. Analysed countries are considered as a region, which is based on similarities emanating from historical, cultural development and experiences. Two countries Malta and Cyprus also joined the EU at the same time; however, they are not included in the analysis, as the differences in historical and cultural development may influence the study results.

Tasks of the study include calculation of coefficient of variation, convergence assessment and analysis of real changes of indicators within chosen group of countries and comparison to EU27 countries on average.

Methods applied in the paper include literature review, data gathering and analysis, calculation of coefficient of variation and comparative analysis.

\section{Regional sustainable development and peculiarities of the countries in Central and Eastern Europe}

Over the last decades, the concept of sustainable development has become as the main vision for further development. The essence of sustainable development is sufficiently clear, though in the different countries and regions principles of sustainable development and main goals can be quite different (Čiegis, 2004).

In Johannesburg Summit (2002) sustainable production and consumption has been recognized as one of the main conditions for the implementation of sustainable development as high dependence on consumption of natural resources pose grave risks of the processes of global sustainable development. For a long time it has been focusing on the production side then analysing the economic impact on the environment, and consumption related environmental problems has been to a certain degree neglected. Over the recent years, this approach has changed significantly and the impact of consumption on the environment is taken into account equally. One of the seven sustainable development aims of EU strategy is also to achieve sustainable production and consumption (EU Sustainable Development Strategy, 2006).

Sustainable regional development is a part of the global sustainable development (Čiegis, 2004). Thus, the importance of regional policy both in countrywide and internationally is increasing. Although in terms of sustainable development there are large differences between developed countries and developing countries, however, the principles of the sustainable development allows less developed countries to develop more evenly, thus, there is an opportunity to reach rather quickly the level of developed countries (Kosiedowski, 2010). Disparities in EU regional development and growing gap between regions are a well-understood problem, but its solutions are not obvious (Čiegis, 2009). As stated by EU strategy for sustainable development (2006) the disparities in social and economic development and differences in well-being of societies are one of the largest threats for sustainable development (EU Sustainable Development Strategy, 2006). And it is extremely difficult to ensure sustainable economic, social and environmental development of the regions and within countries (Dumčius, 2004). Not only Lithuania, but also other new EU Member States are trying to catch up to the overall EU countries on average and to reduce disparities in development between regions of countries. Regional disparities are important because they can hamper the realization of the objectives of national regional policy. Therefore, regional policy plays a crucial role reducing disparities within the regions to promote sustainable development (Mačys, 2006; Malais, Heageman, 2009). However, regional policy too little integrates into other scopes of public policy and, therefore, lacks content, complexity and consistency. 
The regional disparities could be classified based upon their character including reduction of the regional differences: saving and capital accumulation; free movement of factors of production (the capital transition will tend to the poor regions, while the labour force has to move to the rich regions); new technologies have also transferred from rich to the poor regions (Sakalas, 1999). The main causes of the regional differences are: natural and climatic living conditions in the regions; amount of natural resources and their quality; regional status and geographic location; outdated production structure and untimely introduction of innovations; agglomeration advantages and disadvantages; level of technological enlargement; demographic differences; business conditions; political and institutional factors; social and cultural factors (Armstrong, Taylor, 2004).

It is apparent issue of multiple regions of the EU enlargement, expressing uneven social and economic development (Castka, Balzarova, 2007). These issues can be quite multi-faceted:

- uneven development in different European regions, both in regional and individual countries as well as groups wide;

- differentiation between countries and regions in Central and Eastern Europe and as the overall level of social and economic well-being of Eastern and Central European countries; the main standards of socio-economic and technological progress implemented by the European Union;

- social and economic development in the Eastern and Central European countries, expressing the uneven risks of regional enlargement, posed within country.

They can lead to the changes in recent socio-economic development and raise long-term obstacles, as well as historical, cultural, political position of the countries. On the other hand, peculiarities and transformations that have been undergoing in CEE could be a factor changing the whole EU (Melnikas, 2013).

\section{Assessing convergence}

Over the past decade, the debates of convergence have become one of the priority topics in the economic analysis. The earliest interest in the measurement of regional convergence is expressed by R. Easterlin (1960), G. Borts and J. Stein (1964).

These types of economic convergence can measure regional economic convergence: beta-convergence and sigma-convergence. Beta-convergence occurs when poor regions grow faster than rich ones. Sigma-convergence is arbitrary measurement of inequality and dispersion among regions at a particular time. R. Barro and X. Sala-i-Martin (1992) argue that interregional convergence is more likely than between countries as regions as interregional mobility of factors of production is bigger. Most of the empirical works have been examining the EU regional disparities and their convergence (Barro and Sala-I-Martin, 1992; Barro and SalaI-Martin, 1995; Sala-I-Martin, 1996; Quah, 1996; Álvarez-Garcia et al., 2004, Liobikiene, Mandravickaite, 2011). Usually economic aspects are analysed, hence some studies (for ex. Liobikiene, Mandravickaite, 2013) have already introduced some issues on the convergence of environmental performance and so on.

Analysis and convergence covers the major sustainable consumption and production indicators in this paper:

- Domestic Material Consumption (DMC) (tonnes per inhabitant).

- Municipal waste (kilograms per inhabitant).

- Emissions of carbon dioxide (tonnes $\mathrm{CO}_{2}$ equivalent per capita).

- Electricity consumption of households (tonnes of oil equivalent per inhabitant).

- Motorisation rate (cars per 1000 inhabitants).

- Final energy consumption efficiency (1000 PPS/tonnes).

- DMC efficiency (1000 PPS/tonnes).

Convergence rate is expressed with the coefficient of variation $\left(C_{v}\right)$, which is a normalized measure of dispersion of a probability distribution. It represents the ratio of the standard deviation to the mean, and it is 
useful statistic for comparing the degree of variation. $C_{v}$ is calculated using the following formula:

$$
C_{v}=\mathrm{SD} / \bar{x}
$$

where:

$S D$ - standard deviation;

$\bar{x}$ - mean.

Convergence refers to a reduction of the dispersion of levels across regions in time. A negative coefficient (a) obtained in regression equation indicates that convergence is occurring.

3. Convergence of sustainable production and consumption in CEE EU Member States 2000-2010

European Union sets out objective of promoting economic and social cohesion between the member states and regions. New Member States of the EU economics usually grow faster than the old ones, so countries should catch up and become of the same level of development. One of the priorities of sustainable development is to reduce regional disparities of living standards. Despite declared goals inequality grows up in different areas and the cohesion is occurring very slowly (EU Sustainable Development Strategy, 2006).

In the beginning of the period under analysis GDP per capita among the EU Member States was significantly different and the coefficient of variation was higher than in 2010 (Figure 1). It has declined evenly from 0.3 to 0.2 over the period from 2000 to 2007; however, the coefficient of variation increased due to the global economic crisis in 2009. Consequently, a disparity of economics between member states has slightly increased.

Disparities in resource consumption depend much on the available amount of resources within the countries as well as import. Increasing Domestic Material Consumption (DMC) is based mainly on rising import in EU. However, energy efficiency improvements and the rapid transition to other types of fuels have apparently led to decline use of fossil fuel. On the other hand, it is foreseen that biomass extraction will increase by about $35 \%$ and the use of mineral resources for a variety of infrastructure construction projects are expected to increase by $140 \%$ (Monitoring report of the EU sustainable development strategy, 2011).

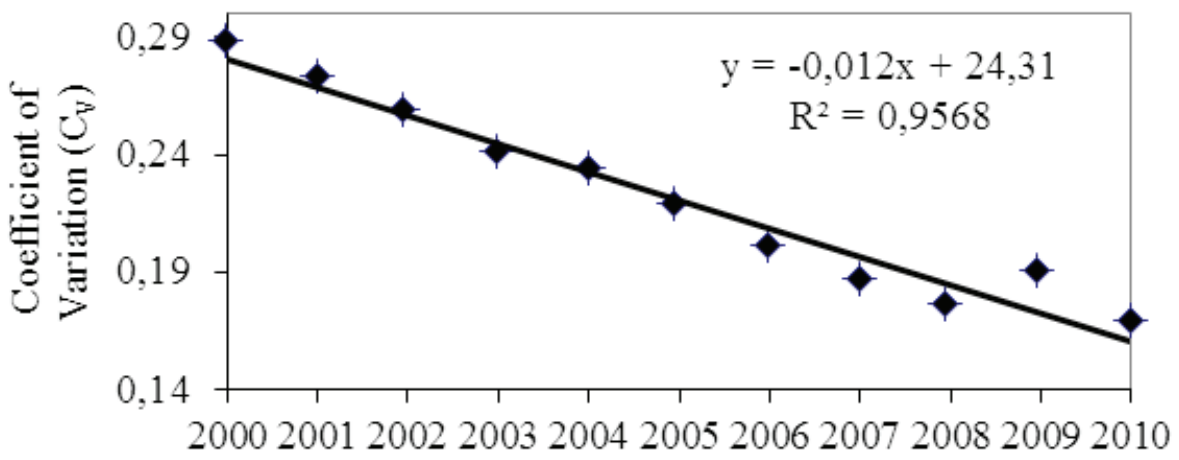

Figure 1. GDP (PPS per capita) - coefficient of variation in EU8 over the period of 2000-2010

Source: authors' calculations based on Eurostat

Analysis of Domestic Material Consumption (DMC) per inhabitant between member states revealed large differences between countries and there was almost no approaching to the overall average of the countries observed (Figure 2). Over the whole period under analysis, the coefficient of variation ranged unevenly. Given the recent economic situation, it is probable that the economy recovery in countries with relatively low DMC would precede faster following increase in production and consumption needs. In addition, as 
predicted, the use of material will only increase in these countries. Therefore, although the disparities between member states will decline, focus on more environmentally consumption habits and improving ecoefficiency is needed.

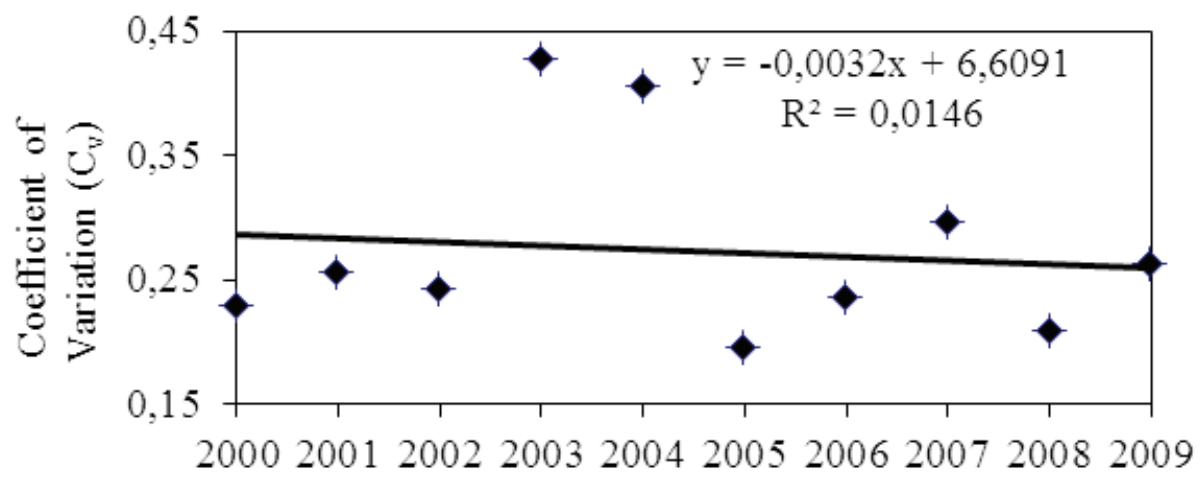

Figure 2. DMC (tonnes per inhabitant) - coefficient of variation in EU8 over the period of 2000-2009

\section{Source: authors' calculations based on data Eurostat}

The coefficient of variation of the amount of municipal waste generated per inhabitant has ranged during the analysis period: it had decreased when countries have joined the EU in 2004, but have increased due to the global economic crisis recently. Some differences between member states according to the municipal waste per inhabitant remained, but they are decreasing (Figure 3).

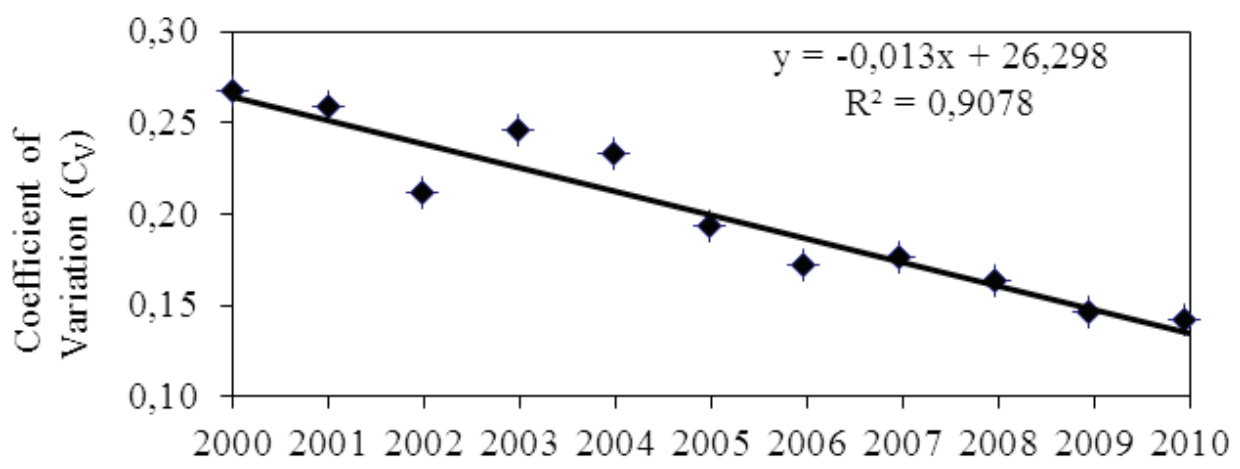

Figure 3. Municipal waste (kg per inhabitant) - coefficient of variation in EU8 over the period of 2000-2010

Source: authors' calculations based on Eurostat

Both the use of resources and the generation of waste per inhabitant have distinct patterns in different countries and it is mainly due to the different economics and social conditions as well as different levels of environmental awareness (Monitoring report of the EU sustainable development strategy, 2011).

Concern has grown over the issue of global climate change in recent years. In 2006 European Union committed to achieve a combined reduction of $20 \%$ in greenhouse gas emissions until 2020 (European Action Plan for Energy Efficiency, 2006).

There are striking differences between countries in emissions of greenhouse gases. However, between 2000 and 2009, emissions of greenhouse gases (GHG) per capita have declined substantially and convergence has been taking place in new EU member states (Figure 4). From environmental point of view countries with high greenhouse gas emissions per capita should tend to reach average of EU8 instead of countries with much lower levels of GHG per capita. 


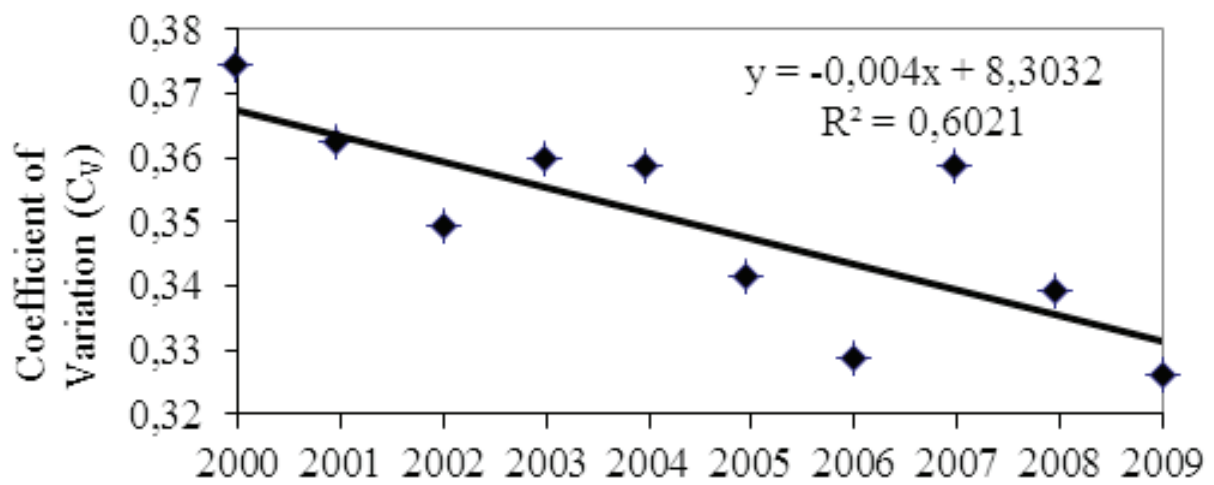

Figure 4. Greenhouse gas emissions (tonnes $\mathrm{CO}_{2}$ equivalent per capita) - coefficient of variation in EU8 over the period of 2000-2009

Source: authors' calculations based on Eurostat

Households are the main consumers and their expenditures have been increasing recently. Moreover, for ex. in Lithuania final household expenditure was 8.91000 PPS per capita and stood already at $94 \%$ of the EU8 average in 2010. Nevertheless, it should be noted that within ES8 countries the final consumption expenditure of households varied significantly. As consumption expenditures relate to the environmental impact (Liobikiene, Mandravickaite, 2013), report on the EU strategy for sustainable development (2011) lays down the need to improve awareness of citizens and to analyse changes in consumers' habits.

Households also are one of the country's largest energy consumers. Households consume about one-third of all the country's final energy consumption: for house heating, hot water systems, lighting, electrical appliances (Monitoring report of the EU sustainable development strategy, 2011). Analysis of convergence of the new EU member states in electricity consumption of households revealed that differences within countries slightly decreased and convergence occurred (Figure 5).

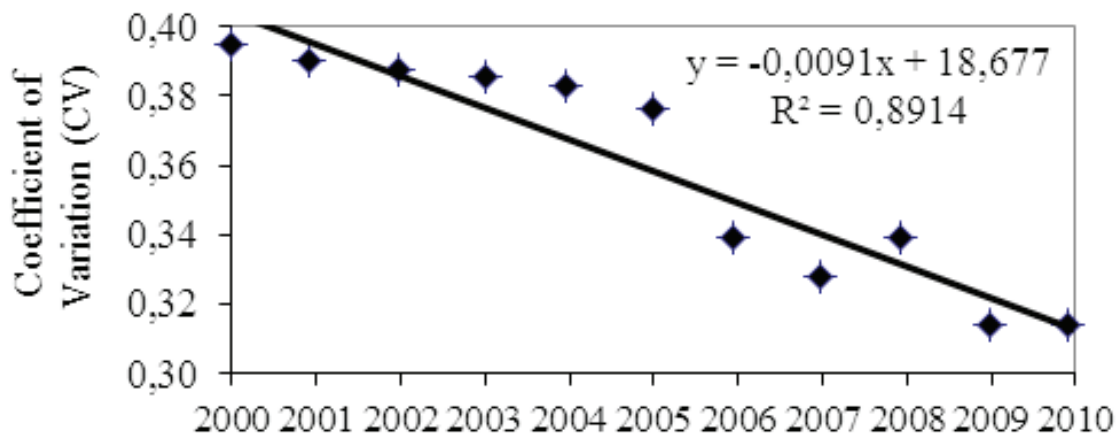

Figure 5. Electricity consumption of households (tonnes of oil equivalent per inhabitant) coefficient of variation in EU8 over the period of 2000-2010

Source: authors' calculations based on Eurostat

Even countries of similar wealth have very different rates of motorisation. However, this indicator has been only increasing in all new member states and difference between countries has declined. The coefficient of variation of the rate of motorisation per 1000 inhabitants declined from 0.28 in 2000 to 0.21 in 2008 (Figure 6). Despite coefficient slightly rose due to the global economic crisis in 2009, convergence between Member States is slowly occurring. 


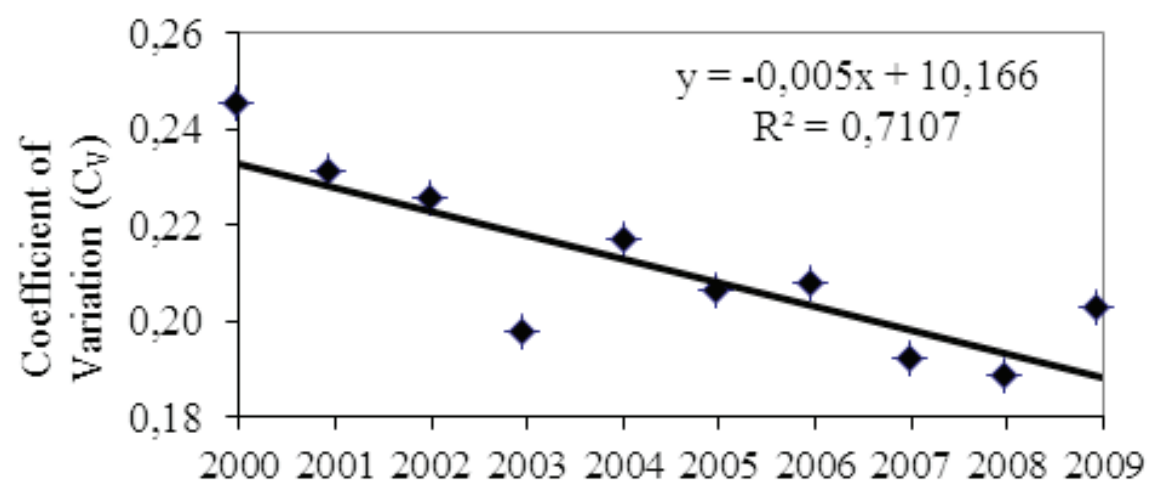

Figure 6. Motorisation rate (cars/1000 inhabitants) - coefficient of variation in EU8 over the period of 2000-2009

Source: authors' calculations based on Eurostat

Renewed EU strategy for sustainable development (EU SDS, 2006) is aiming to improve the quality of life of citizens through the creation of sustainable communities that are able to manage and use resources efficiently. It is important not only to decouple economic growth from environmental pressures but also to achieve efficiency in material use, which allows maximizing the economic and environmental benefits. The proposal for the $7^{\text {th }}$ EU Environment Action Programme ( $7^{\text {th }}$ EAP) aims towards a resource and energy efficient production and consumption patterns and recalls for absolute reduction of resource consumption reducing Ecological Footprint $50 \%$ by 2020 . Therefore, changes in resources efficiency and energy efficiency (GDP unites per resource or energy consumed) are presented in this paper.

At the beginning of the analysis period the lowest resource (DMC) efficiency (0.63 $1000 \mathrm{PPS} /$ tonnes) was in Estonia and Poland, meanwhile the highest (0.95 $1000 \mathrm{PPS} /$ tonnes) was registered in Slovakia. Until 2009, the efficiency of DMC has increased in all countries (Figure 7). The most significant increase of DMC efficiency was in Hungary (61 \%) and the lowest in Estonia (only $2 \%$ ). However, in 2009 to compare to new Member States (EU8) on average, this indicator was $36 \%$ higher in Hungary and $38 \%$ lower in Estonia.

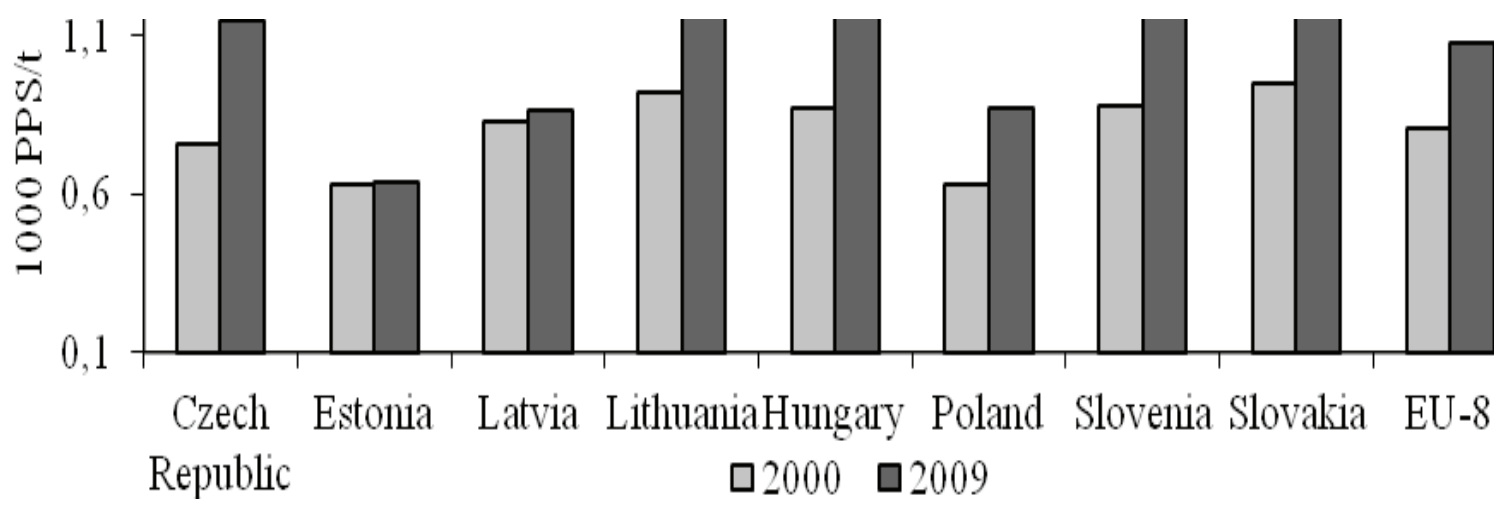

Figure 7. Differences in Domestic Material Consumption efficiency (1000 PPS/tonnes) in EU8 over the period of 2000-2009

Source: authors' calculations based on Eurostat

As indicated by the results (Figure 8), differences in Domestic Material Consumption efficiency have only increased between new EU Member States during the period of 2000-2009 (Figure 7, 8). The coefficient of variation of this indicator rose from 0.15 in 2000 to 0.25 in 2009, i.e. differences in resources efficiency between the new EU8 states are increasing and divergence has been taking place. 


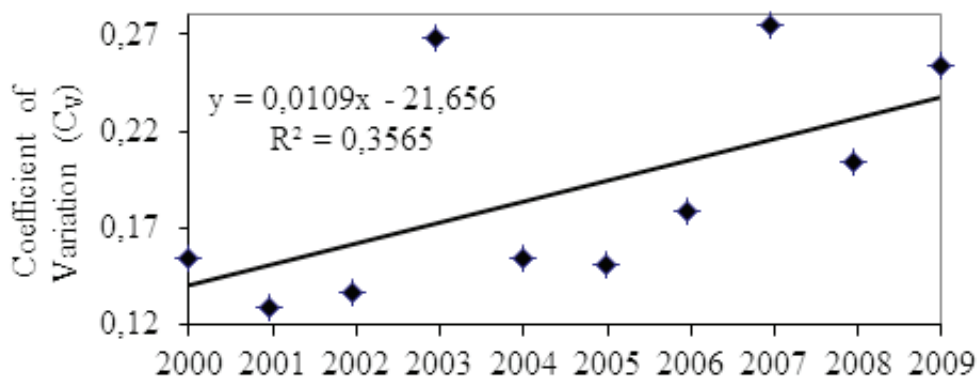

Figure 8. DMC efficiency (1000 PPS/tonnes) - coefficient of variation in EU8 over the period of 2000-2009

Source: authors' calculations based on Eurostat

Energy efficiency is the most effective way to reduce both the amount of energy resources and carbon dioxide emissions. As data (Figure 9) reveals all countries under analysis has improved in this area. The lowest energy efficiency (4.86 1000 PPS/tonnes and 4.891000 PPS/tonnes respectively) was registered in Estonia and Slovakia to compare to other member states in 2000. The highest rate was registered in Slovenia and Lithuania respectively $6.851000 \mathrm{PPS} /$ tonnes and $6.991000 \mathrm{PPS} /$ tonnes. Until 2010, energy efficiency increased in all countries: mostly increased in Slovakia $-72 \%$, in Hungary $-45 \%$, at least increased in Latvia - $30 \%$.

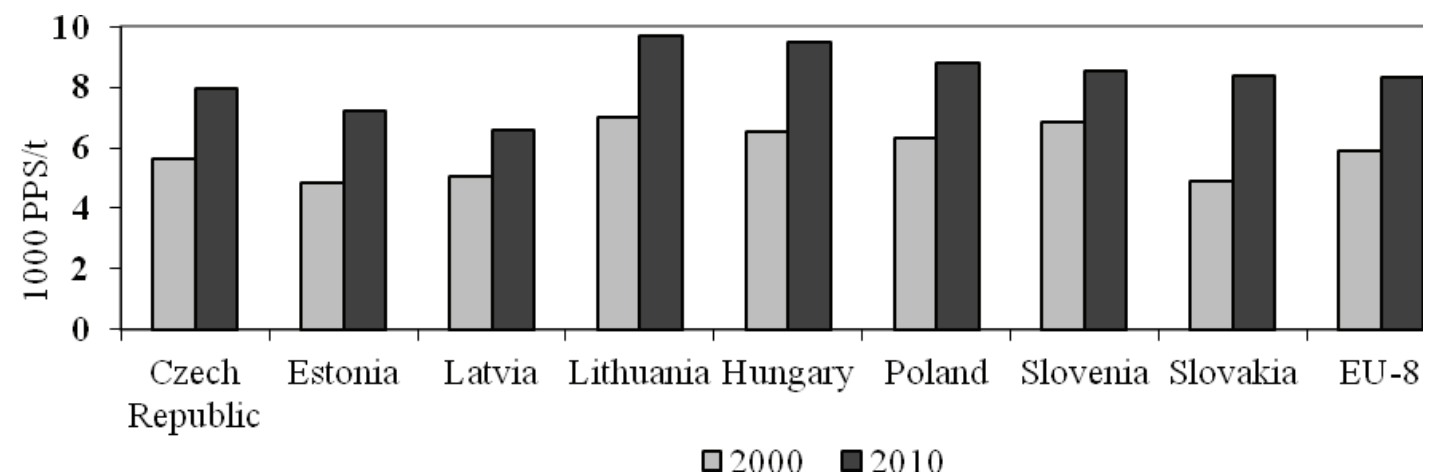

Figure 9. Differences in final energy consumption efficiency (1000 PPS/tonnes) in EU8 over the period of 2000-2010

Source: authors' calculations based on Eurostat

Analysis of convergence in final energy consumption efficiency (Figure 10) between new member states (EU8) reveals that the coefficient of variation has declined during 2000-2007. It should be noted that the coefficient of variation decreased significantly since 2004, when countries joined the European Union, however the economic crisis have hampered these positive trends. Despite differences remain (Figure 9), the convergence between EU8 states is occurring (Figure 10).

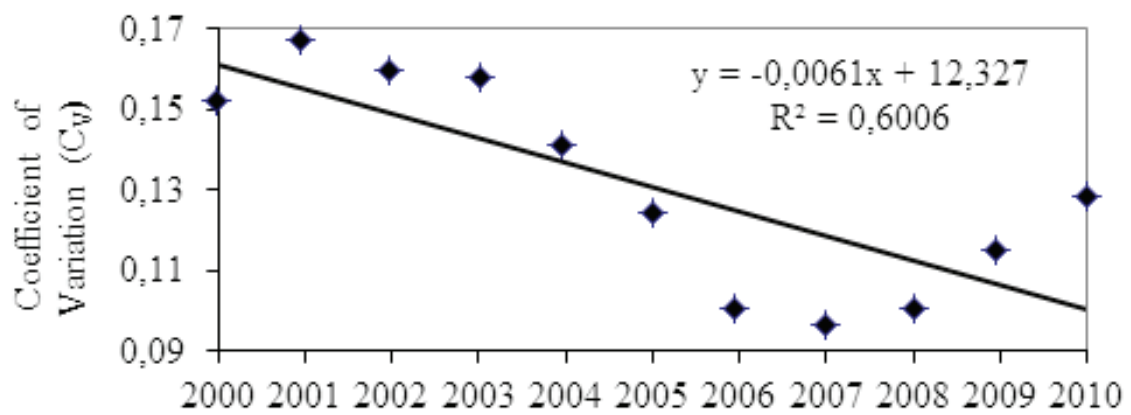

Figure 10. Final energy efficiency (1000 PPS/tonnes) - coefficient of variation in EU8 over the period of 2000-2010

Source: authors' calculations based on Eurostat 
Recent economic crisis have influenced the process of convergence in EU8. Almost in all analysed cases, increasing disparities in consumption and production indicators are observed from 2008 or 2009. However, it concludes that, despite of the existing differences in development, the new (EU8) Member States have been approaching to the group on average according to the analysis of the main sustainable consumption and production indicators, except the material consumption efficiency (Figure 11). Despite that, Lithuania is still behind in terms of GDP per capita and the rate of material efficiency. In terms of GDP per capita Lithuania is lacking behind by $45 \%$ from EU27 on average and from the new countries EU8 on average - $12 \%$. In accordance with the material efficiency, Lithuania is behind the EU27 countries on average by $52 \%$ and from the EU8 countries on average by $16 \%$. According energy efficiency, Lithuania was behind the EU27 countries on average by $12 \%$; but by $9 \%$ ahead the new countries EU8 on average.

It should be noted that faster convergence to the EU8 or EU27 on average should be taking place in countries with higher than on average pollution and waste generation not visor versa. For example, waste generation is lower in Lithuania compared to the EU27 countries on average and emissions of climate change gases are lower to compare to the EU8 countries on average; and these levels should be at least maintained instead of catching up levels of EU8 or EU27. This means, countries with relatively higher pollution and waste generation should attempt to draw closer to the average of countries and countries with lower pollution rates should at least retain them. In this case, regarding environmental aspects, countries in CEE should at least maintain waste generation and emission levels, but improve in energy and material efficiency. Hence, from the point of sustainability, convergence is positive only in the case then countries converge to the lower levels of consumption and production related environmental impacts or improved performance.

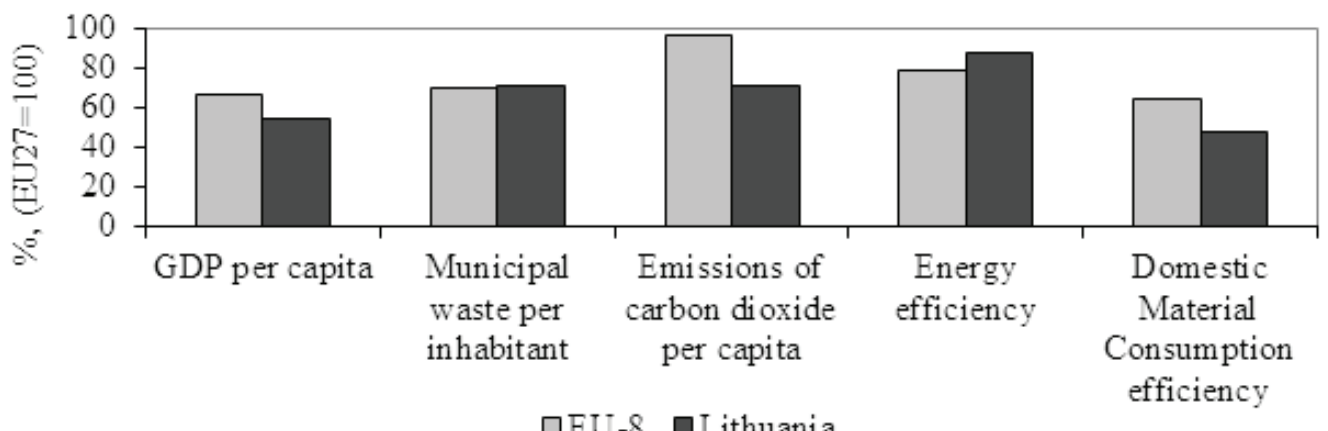

Figure 11. Changes in various indicators $(\mathrm{ES} 27=100 \%)$ in EU8 and Lithuania in year 2009

Source: authors' calculations based on Eurostat

Conclusions

Despite differences between CEE countries disparities are decreasing in most analysed cases. Convergence occurs in the case of GDP, municipal waste generation, greenhouse gas emissions, electricity consumption in households, motorisation rate. Divergence is characteristic for the indicators like DMC and DMC efficiency, though in overall numbers all countries have made some progress in this field.

New EU member states have been approaching to the group on average according to the economic indicators and this is positive feature; but in terms of sustainable development, convergence not always indicates positive changes. The initial values and their trends have to be taken into account. The latter is especially applicable in the environmental field as convergence to the higher pollution levels; resource consumption or lower efficiency is not a desirable direction. Hence countries with higher pollution and waste generation should attempt to draw closer to the countries on average and countries with lower pollution rates should at least retain them; and oppositely, in the case of resource efficiency. 
To conclude, new EU Member States while striving to reach economic level of EU27 on average should maintain still lower levels of consumption, waste generation and pollution. Nevertheless, much more attention to energy and resource efficiency and decoupling of economic growth and resource consumption is to be paid, especially taking into account the impact of economic crisis on these indicators.

\section{References}

Álvarez-Garcia, S., Prieto-Rodriguez, J., Salas, R. (2004). The Evolution of Income Inequality in the European Union during the period 1993-1996. Applied Economics, Vol. 36, No. 13, p. 1399-1408.

Armstrong, H., Taylor, J. (2004). Regional economics and policy. Oxford: Blackwell.

Barro, R., Sala-i-Martin, X. (1995). Economic Growth. 2nd edition MIT Press.

Barro, R. J., Sala-I-Martin, X. (1992). Convergence. Journal of Political Economy, Vol. 100, No. 2, p. 223-251.

Borts, G., Stein J. (1964). Economic growth in a free market. New York: Columbia University Press.

Castka, P., Balzarova, M. (2007). A critical look on quality through CSR lenses. International Journal of Quality and Realiability Management, No. 7, p. 738-752.

Čiegis, R. (2004). Ekonomika ir aplinka: subalansuotos plètros valdymas. Kaunas: VDU leidykla, 552 p.

Čiegis, R. (2009). Darnaus vystymosi vertinimas. Taikomoji ekonomika: sisteminiai tyrimai, Nr. 3 (1), p. 105-122.

Commision of European Communities. (2006). Action Plan for Energy Efficiency: Realising the Potential. COM(2006) 545 final, Brussels.

Council of the European Union. (2006). Renewed EU Sustainable Development Strategy. Doc. 10917/06, Brussels.

Dumčius, R. (2004). Europos Sajungos regioniné politika Lietuvoje - problemos ir galimybès. Viešosios politikos ir vadybos institutas.

Easterlin, R. A. (1960). Interregional differences in per capita income, population, and total income, 1840-1950. In: Trends in the American economy in the nineteenth century. A report of the National Bureau of Economic Research, p. 73-140. Princeton: Princeton University Press.

Eurostat. (2011). Sustainable development in the European Union 2011 monitoring report of the EU sustainable development strategy. Luxembourg: Publications Office of the European Union.

Kasinskaite, I. (2005). Besimokantis regionas - naujas regioninès plètros kontekstas. Informacijos mokslai, Nr. 35, p. $59-68$.

Kosiedowski, W. (2010). Macroeconomic conditions of sustainable development on the borderline of the European Union and the Commonwealth of Independent States. Kapital ludzki w procesie przemian Europy srodkowej $i$ wschodniej. Torun: Poland.

Liobikienè, G., Mandravickaite, J. (2011). Achievements of Lithuanian Sustainable Development during the Integration Process into the European Union. Technological and Economic Development of Economy, Vol. 17, No. 1, p. 62-73.

Liobikiene, G., Mandravickaite, J. (2013). Convergence of new members of the EU: changes in household consumption expenditure structure regarding environmental impact during the prosperous period. Environment, Development and Sustainability, Vol. 15, No. 2, p. 407-427.

Mačys, G. (2006). Regionų ekonomika, politika ir valdymas Lietuvoje. Vilnius: Mykolo Riomerio universitetas.

Malais, J., Heageman, H. (2009). European Union Regional Policy. Analysis on the European Union Regional Policy. Avalaible at: http://www.iiuedu.eu/press/journals/sds/sds1_july_2008/07_SECC 03.pdf (accessed 12 April, 2012).

Melnikas, B. (2013). Transformations and Regional Economic Development in Central and Eastern Europe: Typicalities and New Perspectives. Regional Formation and Development Studies, Journal of Social Sciences, Vol. 1, No. 9, p. 102-112.

Quah, D. T. (1996). Empirics for economic growth and convergence. European Economic Review, Vol. 40, No. 6, p. $1353-1375$.

Sakalas, A. (1999). Regioninis mokymo ir kvalifikacijos kèlimo aspektas. Socialiniai mokslai, Nr. 2 (19), p. 39-46.

Sala-I-Martin, X. (1996). Regional cohesion: Evidence and theories of regional growth and convergence. European Economic Review, Vol. 40, No. 6, p. 1325-1352.

Šidlauskiené, I. (2000). Europos Sajunga iš arčiau. Suomijos viešojo administravimo institutas (HAUS), 192 p. 


\section{PAGRINDINIU DARNIOS GAMYBOS IR VARTOJIMO RODIKLIU KONVERGENCIJA NAUJOSIOSE ES ŠALYSE NARÉSE 2000-2010}

Inga UŽDANAVIČIUTtè, Renata Dagiliūtè

Vytauto Didžiojo universitetas (Lietuva)

Santrauka

Vienas pagrindinių ES plètros tikslų - konvergencija. Ekonominio augimo metu (2000-2007 m.), remiantis dauguma analizuotų darnaus vartojimo ir gamybos rodiklių, išskyrus medžiagų vidaus suvartojimą, šalys suartèja viena su kita, vyksta konvergencija. Tačiau pasaulinės ekonominės krizès padariniai $2009 \mathrm{~m}$. padidino skirtumus tarp šalių: konvergencijos rodiklis - variacijos koeficientas - didejjo. Tačiau kalbant apie darnų vystymąsi konvergencija ne visada rodo teigiamus pokyčius. Naujosios ES šalys narès turètų stengtis siekti aukštesnio ekonomikos lygio ir išlaikyti žemesnį vartojimo, atliekų susidarymo ir taršos lygí. Daugiau dẻmesio reikètų skirti energijos ir išteklių efektyvumui ir stengtis atsieti ekonomini augimą nuo išteklių vartojimo.

PAGRINDINIAI ŽODŽIAI: Centrine ir Rytu Europa, darnus vartojimas ir gamyba, darnus regionu vystymasis, konvergencija.

JEL KLASIFIKACIJA: Q560, R110, O570, Q010 